\title{
平面クエット乱流に現れる大規模ストリークの空間構造の解明*
}

\author{
梅 木 雅 之草，鬼 頭 修 己*2
}

\section{Spatial Structure of Large Scale Streaks in Turbulent Couette Flow}

\author{
Masayuki $\mathrm{UMEKI}^{* 3}$ and Osami KITOH \\ ${ }^{* 3}$ Department of Mechanical Engineering, Nagoya Institute of Technology, \\ Gokiso-Cho, Showa-ku, Nagoya-shi, Aichi, 466-8555 Japan
}

\begin{abstract}
The spatial structure of large scale streaks in core region of turbulent Couette flow has been studied by using data from hot-wire and smoke-wire visualization. To extract the large scale streaks, two-dimensional discrete wavelet energy spectrum and spanwise correlation of streamwise velocity $u_{1}^{\prime}$ were considered. The spanwise size of the extracted large scale streaks is of the order of the channel hight $(2 h)$ and the streamwise length of $(10 \sim 40) \times 2 h$. The streak has partly a $z i g-z a g$ pattern along streamwise direction and partly straight. The zig-zag pattern has $(20 \sim 25) \times 2 h$ streamwise wavelength. From the visualization of cross section $\left(x_{2}, x_{3}\right)$ there exist a large scale motion related to the streamwise vortex in core region. Some near-wall ejection motions are connected to the large scale motions.
\end{abstract}

Key Words: Turbulent Couette Flow, Large Scale Streaks, Longitudinal Vortical Structure, Wavelet Transform, Flow Visualization

\section{1. 緒 論}

平行平板間クエット乱流の流路中央部には, 主流方 向に伸びた大規模な縦渦が存在していることが知られ ている. Komminahoら (1) は, DNSによりこの縦渦 が時間的にも定常でなく, 空間的にも一様でないと報 告している.この縦渦に付随して高速・低速のストリ ークが現れる. Tillmark ら(2)は, PIVによる測定に より, クエット乱流の流路中央において流路高さ程度 の幅をもつストリーク構造の存在を示した. 著者らは 前報(3)において縦渦の生成機構を渦度輸送方程式に 基づいて調査した。しかしながらこれらストリークや 縦渦の空間構造の詳細については未解明のままであ る.

Hamilton ら (4) は, 壁組織構造の再生サイクル解明 のためミニマル平面クエット乱流のDNSを行い, 流 路中央部に現れるストリークと縦渦の再生サイクルを 示した。そのサイクルでは, ストリークは縦渦により

\footnotetext{
$*$ 原稿受付 2003 年 9 月 29 日.

*1 正員, 名古屋工業大学大学院生産システム工学専攻(- 4668555 名古屋市昭和区御器所町).

*2 正員, 名古屋工業大学工学部.

E-mail : umeki@cfd.mech.nitech.ac.jp
}

生成され，縦渦はストリークのスパン方向への摇らぎ により生成される。また, Kawahara-Kida(5) は, 同 様のミニマル平面クエット乱流の DNSにより, 乱流 中に埋め込まれた周期軌道を見いだし，この周期軌道 が Hamilton らの再生サイクルに対応していることを 示した.これらミニマル平面クエット乱流中のストリ 一ク・縦渦構造と Komminaho ら (1) や著者ら ${ }^{(3)}$ が報 告している大規模縦渦あるいはストリーク構造との関 連は明確になっていない. 最近, Kim-Adrian ${ }^{(6)}$ は, 高レイノルズ数の円管乱流を熱膜により測定し, 外層 において主流方向に伸びた構造が存在することを示し た.このように平面クエット乱流や高レイノルズ数の ポアズイユ乱流の外層には大規模なストリークあるい は，縦渦構造が見いだされてきているが，それらの空 間構造, 壁組織構造との関連, 生成メカニズム等末解 明な点が多く残されている.

本研究では, 平面クエット乱流中に現れる大規模な ストリーク構造に焦点を絞り, 多チャネル熱線による 速度分布測定とスモークワイヤ法による可視化により 得られた空間的な速度分布にウェーブレット分析など を用いることにより，その空間構造について考察を行 った. 


\section{2. 記 号}

$E_{j_{1}: j_{3}}$ : スケールパラメータ $j_{1}$ と $j_{3}$ に関するウェー ブレットエネルギースペクトル

$2 h:$ 流路高さ

$j_{i}: i$ 方向のスケールパラメータ

$k_{i}: i$ 方向のトランスレートパラメータ

$R e_{b}:$ レイルズ数 $=\frac{2 h U_{b}}{\nu}$

$R e_{c}:$ レイルズ数 $=\frac{2 h U_{c}}{\nu}$

$R e^{*}:$ レイノルズ数 $=\frac{h u_{*}}{\nu}$

$t:$ 時間

$U_{b}:$ ベルト速度

$U_{c}:$ 流路中央の平均速度

$U_{w}:$ 上壁と下壁の相対速度の半分 $\quad=U_{b} / 2$

$u_{*}$ : 摩擦速度 $=\sqrt{\frac{\left|\tau_{w}\right|}{\rho}}$

$u_{i}^{\prime}: i$ 方向の変動速度

$\tilde{u}_{1_{1,}, k_{1}: j_{3}, k_{3}}: u_{1}^{\prime}\left(x_{1}, x_{3}\right)$ のウェーブレット係数

$\nu:$ 動粘度

$\Psi_{j_{1}, k_{1}: j_{3}, k 3}:$ ウェーブレット関数

$\tau_{w}:$ 壁面せん断応力

添 字

$i=1,2,3:$ 主流方向, 流路高さ方向, スパン方向

\section{3. 実験装置と方法}

本研究では, ストリークの空間構造の抽出のために 熱線による測定とスモークワイヤ法による可視化を行 った。クエット乱流の実験装置は前報 ${ }^{(3)}$ のものと同 じである，座標は, 流路入口から主流方向に $x_{1}$, 壁面 から流路高さ方向に $x_{2}$, 流路中央よりスパン方向に $x_{3}$ とした。熱線およびスモークワイヤ法による可視 化の測定条件を表 1 に示す.

$3 \cdot 1$ スモークワイヤ法による可視化 スモーク ワイヤ法によるストリークの空間構造の可視化は, 図 1 で示す装置で行った。広い領域にわたる空間構造を 調べるため, 直径 $50 \mu \mathrm{m}$, 長さ $270 \mathrm{~mm}$ のニクロム線 をスモークワイヤとして用い, 流路中央部 $\left[x_{2} /(2 h)\right.$

Table 1 Mesuring conditions

\begin{tabular}{l|l|l}
\hline \hline measurements & $R e_{b}$ & $R e^{*}$ \\
\hline Hot-wire & 15000 & 200 \\
\hline Hot-wire & 10000 & 140 \\
\hline Smoke-wire visualization & 7000 & 100 \\
\hline
\end{tabular}

$=0.5]$ の位置において主流方向に $20 \mathrm{~mm}$ 間隔に 32 本並べた，最上流部の二クロム線は， $x_{1} /(2 h)=120$, 最下流部のニクロム線は, $x_{1} /(2 h)=143$ に設置してあ る. 発煙領域は, 主流方向に $46 h$, スパン方向に $20 h$ である.ニクロム線の両端は $0.3 \mathrm{~mm}$ のピアノ線に はんだ付けしてある，そのピアノ線の端は，ば权に固 定し他方は端子に固定してある. 可視化に用いるス卜 ロボは，上流側の流路の左右に 2 台取付けた。 カメラ はディジタルカメラを 2 台用いて流路のアクリル製の 上壁の上に設置した。発煙剂は流動パラフィンと軽油 が $1: 2$ の割合の混合油を用いた。ワイヤへの通電時 間 $T_{2}$ とワイヤ通電後ストロボ発光までの遅延時間 $T_{d}$ の制御は, PICで行った. 可視化によるストリー ク構造の抽出は以下の手順で行う。まず，ニクロム線 に $T_{\nu}=1.6 \mathrm{~ms}$ だけ通電しタイムラインを発生させ る.このタイムラインを遅延時間 $T_{d}=6 \mathrm{~ms}$ の後, ス トロボを発光させ, 2 台のカメラで撮影する。次に, この撮影写真の夕イムラインから断面 $\left(x_{1}, x_{3}\right)$ 内の変 動速度 $u_{1}^{\prime}\left(x_{1}, x_{3}\right)$ の分布を求める. $u_{1}^{\prime}$ の正と負の分布 を調べることである瞬間の $u_{1}^{\prime}$ のストリークの空間構 造を得ることができる。

大規模縦渦構造を可視化するための流路断面内の可 視化装置を図 2 に示す。 $x_{1} /(2 h)=120$ の断面 $\left(x_{2}, x_{3}\right)$

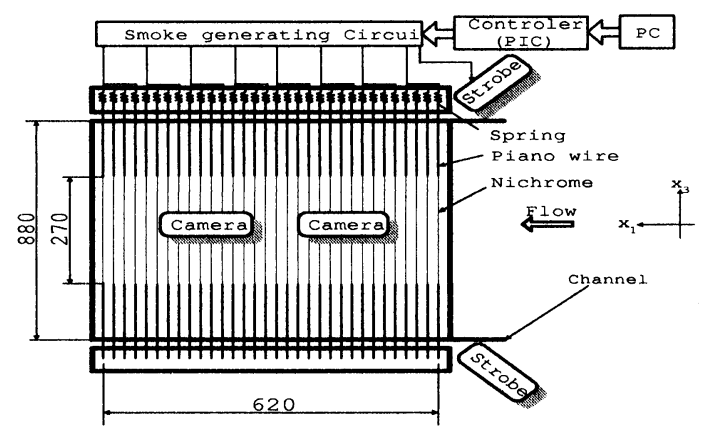

Fig. 1 System of smoke-wire visualization for streaks

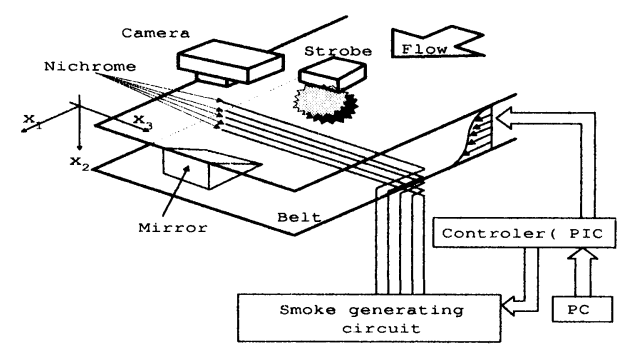

Fig. 2 System of smoke- wire visualization for streamwise vortical structure in cross-section $\left(x_{2}, x_{3}\right)$ 


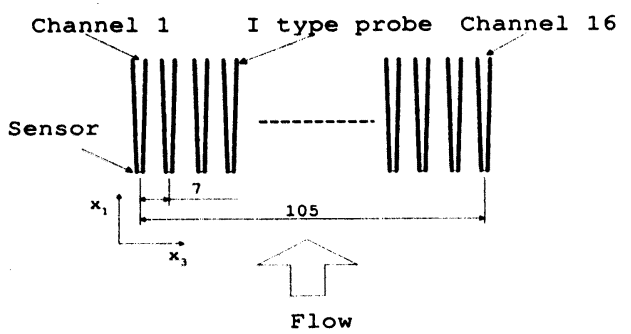

Fig. 316 channel I-type hot-wire probe

内において, ニクロム線をスパン்方向に平行に 4.5 $\mathrm{mm}$ 間隔で 5 本並べた。このときの通電時間は， $T_{\nu}$ $=1.6 \mathrm{~ms}$, 遅延時間は, $T_{d}=10 \mathrm{~ms}$ とした. 可視化は, 上壁の上方に設置してあるストロボを発光させ, 流路 内の上壁に設置した鏡に映った像を流路上壁の上方に 設置してあるカメラで撮影した。

3・2 16 チャネル I 形勢線クエット乱流の流路 中央部における $u_{1}^{\prime}$ のストリークの空間構造を定量的 に調べるためにI 形熱線を 16 本スパン方向に並べた 16 チャネルI形熱線を用いて測定を行った。この 16 チャネル I 形熱線を図 3 に示す。それぞれのI 形熱線 の間隔は, $7 \mathrm{~mm}$ であり, スパン方向の測定範囲は, $105 \mathrm{~mm}$ で流路高さ $(2 h=27 \mathrm{~mm})$ の 4 倍程度である. 測定は, プローブを $x_{1} /(2 h)=120, x_{2} /(2 h)=0.5$ の位 置に設置して, サンプリング周波数 $f=10 \mathrm{kHz}$ で行 った。得られた時系列データをティラーの凍結乱流の 仮説 $\left(x_{1}=-U_{c} \times t\right)$ を用いて時間軸を $x_{1}$ 軸に変換し て空間構造を調べた。

以上, スモークワイヤ法と熱線流速計による測定手 法について述べたが，これらは次に述べるように，ス トリークの空間構造の計測に対しそれぞれ長所と短所 をもっている.スモークワイヤ法は，ある瞬間のスト リークの空間構造を調べることに向いているが定量計 測の精度が低い。これに対し熱線は，定量計測精度は 高いが時系列データからテイラーの凍結乱流の仮説を 用いて空間構造を得るため, 流れ場が仮説成立条件を 満たしていることの確認が必要である。測定領域 $L$ (主流方向長さ) $\times W$ (スパン方向幅) と空間スケール 分解能に関しては, スモークワイヤ法では, $L \times W=$ $46 h \times 12 h$ で主流方向最小分解スケールが $1.5 h$, 熱線 では, $L \times W=\left(U_{c} \times T\right) \times 7.8 h(T$ は, 測定時間 $)$ でス パン方向最小分解スケールが $0.5 h$ である.すなわち, スモークワイヤ法は, スパン方向の測定領域が比較的 広く空間分解能が高いが, 主流方向の測定領域が狭く 分解能が低い。一方, 熱線はこれと逆の性質があり両 者を組合せることにより，互いの短所を補うことがで

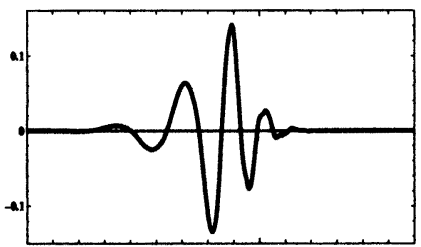

Fig. 4 Daubechies wavelet function with index $N=20$

きる. 4 章で示すように, 両手法により得られるウェ ーブレットエネルギースペクトルおよびスパン方向相 関がほぼ一致することからいずれの手法も同じ空間構 造をとらえており，それぞれの特徴を生かした考察を することができる。

$3 \cdot 3$ 離散ウェーブレット変換 $3 \cdot 1$ 節と $3 \cdot 2$ 節 で得られた変動速度 $u_{1}^{\prime}\left(x_{1}, x_{3}\right)$ から大規模なストリー クを抽出するために $u_{1}^{\prime}\left(x_{1}, x_{3}\right)$ の二次元離散ウェーブ レット変換を行う. 変動速度 $u_{1}^{\prime}\left(x_{1}, x_{3}\right)$ の二次元離散 ウェーブレット変換 $\tilde{u}_{1 j_{1}, k_{1}}: j_{3}, k_{3}$ は, 次式で定義され る(7)

$$
\begin{aligned}
& \tilde{u}_{1 j_{1}, k_{1}}: j_{3}, k_{3} \\
& \quad=\int_{-\infty}^{+\infty} \int_{-\infty}^{+\infty} u_{1}^{\prime}\left(x_{1}, x_{3}\right) \Psi_{j_{1}, k_{1}}: j_{3}, k_{3}\left(x_{1}, x_{3}\right) d x_{1} d x_{3}
\end{aligned}
$$

ここに, $\Psi_{j_{1}, k_{1}}: \dot{j}_{3, k_{3}}\left(x_{1}, x_{3}\right)$ は, ウェーブレット関数で ある.また $j_{1}, j_{3}$ および $k_{1}, k_{3}$ は, それぞれ $x_{1}$ 方向お よび $x_{3}$ 方向のスケールパラメータおよびトランスレ ートパラメータである. スケールパラメータは, 正の 整数の值をとる. 本研究では, その值が大きいほど小 さいスケールを表すこととする. ウェーブレット逆変 換は次式で表される。

$$
\begin{aligned}
& u_{1}^{\prime}\left(x_{1}, x_{3}\right) \\
& \quad=\sum_{j_{1}} \sum_{k_{1}} \sum_{j_{3}} \sum_{k_{3}} \tilde{u}_{1 j_{1}, k_{1}: j_{3}, k_{3}} \Psi_{j_{1}, k_{1}: j_{3}, k_{3}}\left(x_{1}, x_{3}\right)
\end{aligned}
$$

本研究では, Daubechies(index $N=20$ )のウェーブレ ット関数を用いた。この関数を一次元で表したものを 図 4 に示す.ウェーブレットエネルギースペクトル は, ウェーブレット係数の二乗を各方向のトランスレ ートパラメータに関して総和をとったもので定義され る(8).

$$
E_{j_{1}: j_{3}}=\sum_{k_{1}} \sum_{k_{3}}\left|\tilde{u}_{1 j_{1}, k_{1}: j_{3}, k_{3}}\right|^{2}
$$

$E_{j_{1}: j_{3}}$ は, スケールパラメー夕 $j_{1}$ (主流方向) と $j_{3}$ (スパ ン方向）に関するエネルギースペクトルである，本報 では, トータルのエネルギー $\sum_{j_{1}} \sum_{j_{3}} E_{j_{1}}: j_{3}$ で規格化を 行い, 同じ $E_{j_{1}: j_{3}}$ で表す. 


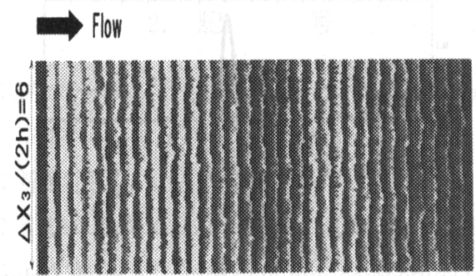

$\Delta x_{1} /(2)=23$

Fig. 5 Flow visualization on $x_{1}-x_{3}$ plane at $x_{2} /(2 h)=$ 0.5

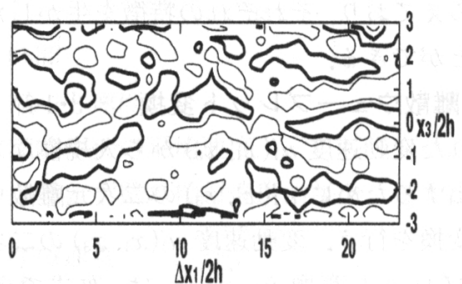

Fig. 6 Equi-velocity contours of $u_{1}^{\prime}\left(x_{1}, x_{3}\right)$ at center plane: thick lines depict $u_{i}^{\prime} / U_{c}=-0.05$ and thin lines $u_{i}^{i} / U_{c}=0.05$

\section{4. 実験結果と考察}

$4 \cdot 1$ クエット乱流におけるストリーク構造 図 5 にスモークワイヤ法から得られた断面 $\left(x_{1}, x_{3}\right)$ の可 視化写真を, また図 6 にその写真から読取った $u_{1}^{\prime}$ の 等值線図を示す. 可視化写真の夕イムラインから変動 速度を読取る際の誤差は, クエット乱流中の大規模構 造で生じる主流方向の変動速度に換算して $20 \%$ 以内 である。この可視化から乱流中の小さいスケールの運 動をとらえることは困難だが，大規模構造の抽出には 問題ないことを熱線流速計による測定結果との比較か ら確認した。また，上流部のスモークワイヤが下流側 へ与える影響を調べるためにポアズイユ乱流において も同じ可視化実験を行った. 上流部のスモークワイヤ と比較して, 最下流のスモークワイヤで観測される夕 イムラインに特に大きな変動は見られなかった。した がって,この手法によるクエット乱流中の大規模構造 の可視化は十分可能であると考えられる．等值線図よ り流路高さ程度の幅をもち, 主流方向に流路高さの 10 倍ほど伸びたストリーク構造を確認することができ る.これらのストリークは主流方向に傾いたものや平 行なものがある. 可視化から得られた $u_{1}^{\prime}\left(x_{1}, x_{3}\right)$ のス パン方向の相関

$$
R_{11}\left(\Delta x_{3} /(2 h)\right)
$$

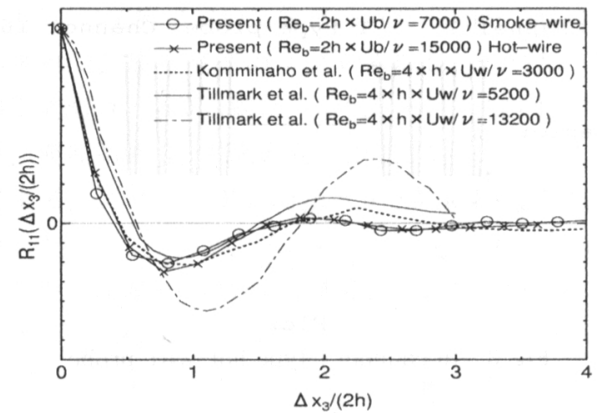

Fig. 7 Spanwise correlations of streamwise velocity

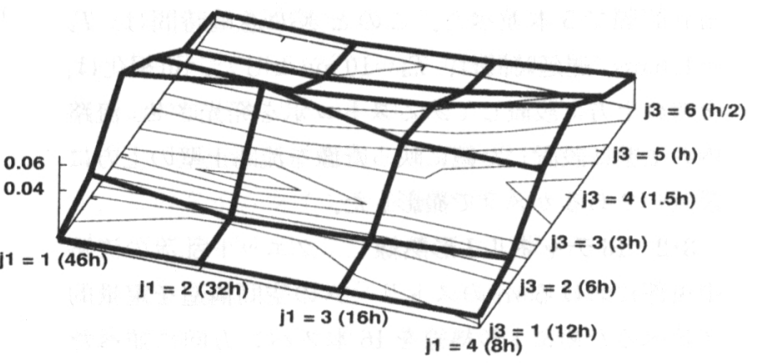

Fig. 8 Wavelet energy spectrum of $u_{1}^{\prime}\left(x_{1}, x_{3}\right)$ measured by flow visualization

$$
=\frac{\int_{-L / 2}^{L / 2} \int_{-H / 2}^{H / 2} u_{1}^{\prime}\left(x_{1}, x_{3}\right) u_{1}^{\prime}\left(x_{1}, x_{3}+\Delta x_{3}\right) d x_{3} d x_{1}}{\int_{-L / 2}^{L / 2} \int_{-H / 2}^{H / 2} u_{1}^{\prime}\left(x_{1}, x_{3}\right) u_{1}^{\prime}\left(x_{1}, x_{3}\right) d x_{3} d x_{1}}
$$

を計算し 5 枚の可視化写真について平均したものを図 7 に示す。上式において， $L$ と $H$ は，それぞれ主流方 向およびスパン方向の可視化領域の長さを表す．この 相関は，スパン方向に波状的に分布しており， $\Delta x_{3} /(2 h)=0.8$ 付近で最小值(約一 0.2$)$ をとる.これ より，ストリークが流路高さ程度の幅をもちスパン方 向に並んでいることがわかる. 本実験で得られた $u_{1}^{\prime}$ のスパン方向の相関は, Tillmark ら (2) $R e_{b}=5200$ のものや Komminaho ら (1) $R \mathrm{Re}_{b}=3000$ のものに近 い. しかし, Tillmarkら (2) の $R_{b}=13200$ での相関 は, $\Delta x_{3} /(2 h)=1$ よりわずかに大きな位置で最小值を とり, 最小值は, -0.4 より小さくなっていて他の場 合と異なった結果となっている，後述する熱線流速計 による結果も含め本研究ではレイノルズ数依存性は見 られず Tillmark らの結果との相違は不明である.

図 8 に可視化から得られた $u_{1}^{\prime}\left(x_{1}, x_{3}\right)$ のウェーブレ ットエネルギースペクトルを示す. 図 8 中, 主流方向 のスケールパラメータは, $j_{1}=1$ から $j_{1}=4$, スパン方 向のスケールパラメー夕は, $j_{3}=1$ から $j_{3}=6$ を示して 


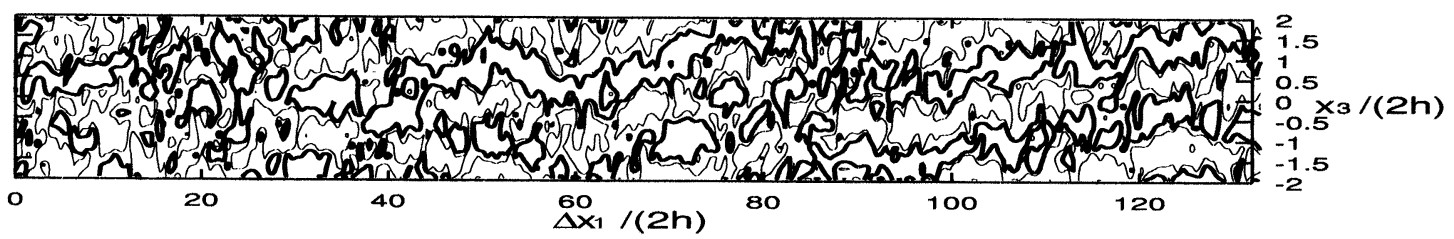

Fig. 9 Equi-velocity contours of $u_{1}^{\prime}\left(x_{1}, x_{3}\right)$ for Couette flow at center plane: thick lines depict $u_{1}^{\prime} / U_{c}=-0.05$ and thin lines $u_{i}^{\prime} / U_{c}=0.05$

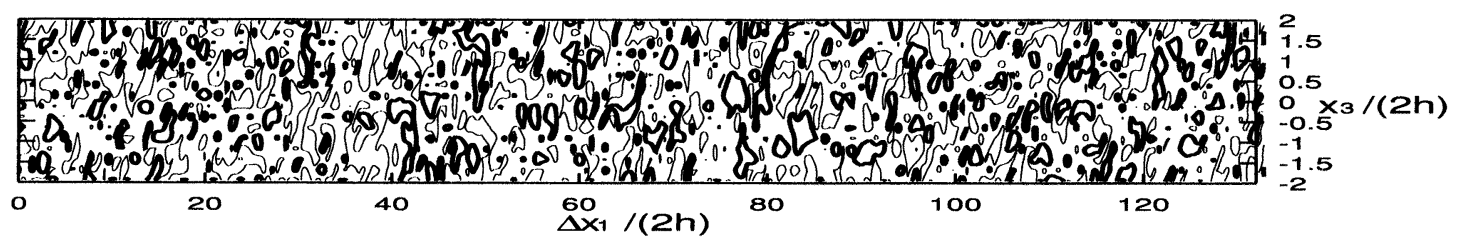

Fig. 10 Equi-velocity contours of $u_{1}^{\prime}\left(x_{1}, x_{3}\right)$ for Poiseuille flow at center plane : thick lines depict $u_{1}^{\prime} / U_{c}=-0.03$ and thin lines $u_{i}^{\prime} / U_{c}=0.03$

1: : Couette flow $\mathrm{Re}_{\mathrm{b}}=\mathbf{1 5 0 0 0}$

: Couette flow $R e_{b}=15000$ with V.G

$\triangle$ : Poiseuille flow $R_{\theta_{c}}=7500$

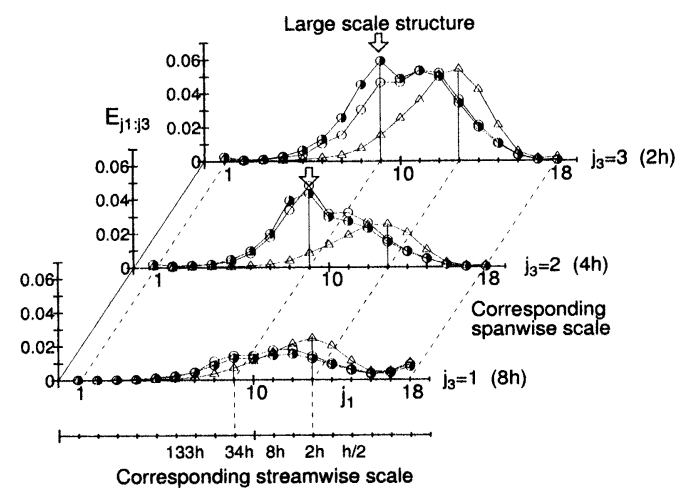

Fig. 11 Wavelet energy spectrum of $u_{1}^{\prime}\left(x_{1}, x_{3}\right)$

ある.参考のために各スケールパラメータ $j_{1}, j_{3}$ に関 して対応する長さスケールを図 8 中(括弧内) に示して ある、記入したスケールは, 大まかな目安で厳密な值 ではない. $E_{j_{1}: j_{1}}$ は, $j_{3}=3$ (ほほ流路高さ $2 h$ に対応す

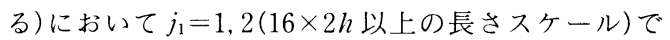
大きな值をとる.これは, 主流方向に $16 \times 2 h$ 以上伸 びて, $2 h$ 程度の幅をもったストリークがスパン方向 に交互に並んでいることを示しており, 図 7 で示した スパン方向の相関が $\Delta x_{3} /(2 h)=0.8$ 付近で最小值を とることに対応している.

可視化で得た $u_{1}^{\prime}\left(x_{1}, x_{3}\right)$ の分布はある瞬間の空間構 造をとらえるには適しているが, 可視化でとらえるこ とのできる主流方向の長さは $46 h$ で, それ以上の構造 をとらえることができない，そこで，さらに主流方向

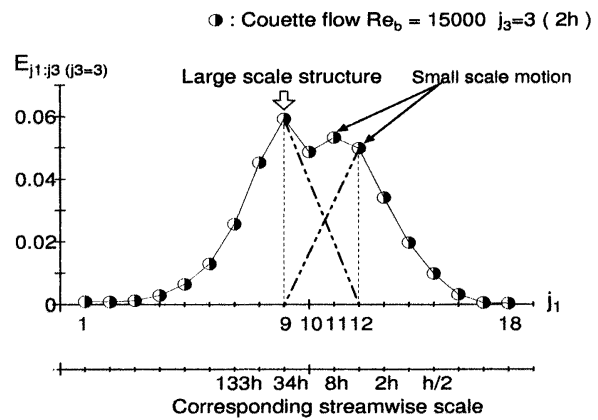

Fig. 12 Wavelet energy spectrum of $u_{1}^{\prime}\left(x_{1}, x_{3}\right)$ at $j_{3}=3$ of Couette flow

の広い領域でクエット乱流のストリーク構造を定量的 に調べるために 16 チャネル I 形熱線による測定を行 つた. $R e_{b}=15000$ の場合に対し 16 チャネル I 形熱 線で測定した主流方向変動速度 $u_{1}^{\prime}$ の時系列にテイラ 一の凍結乱流の仮説を用いて主流方向の座標に換算し た断面 $\left(x_{1}, x_{3}\right)$ 内の $u_{1}^{\prime}\left(x_{1}, x_{3}\right)$ の分布を図 9 に示す. 比較のためにポアズイユ乱流 $\left(R e_{c}=7500\right)$ の測定結果 を図 10 に示す。図 10 よりポアズイユ乱流では, 大規 模な構造は, 明確に確認することはできないが，クエ ット乱流においては主流方向に伸びたストリーク構造 を確認でき，またストリークがスパン方向に摇らいで いることがわかる[図 10 中 $40 \leq \Delta x_{1} /(2 h) \leq 80,0 \leq$ $\left.\Delta x_{3} /(2 h) \leq 2\right]$. また, 大きなスケールの構造が存在す る領域 $\left[\Delta x_{1} /(2 h) \geq 40\right]$ や比較的細かい構造がラン ダムに現れる領域 $\left[\Delta x_{1} /(2 h)<40\right]$ がある.このよ うな $x_{1}$ 方向の構造の変化は, テイラーの凍結乱流の 


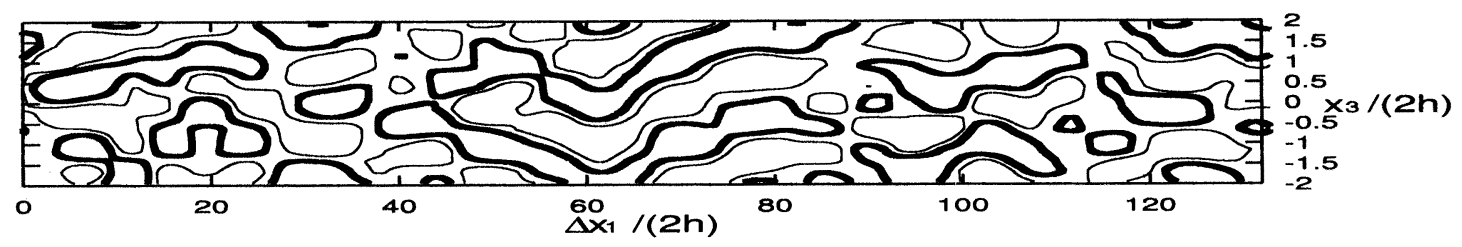

Fig. 13 Equi-velocity contours of $u_{1}^{L}\left(x_{1}, x_{3}\right)$ for Couette flow at center plane : thick lines depict $u_{1}^{\prime} / U_{c}=-0.03$ and thin lines $u_{1}^{\prime} / U_{c}=0.03$

仮説を用いているため, 時間的な構造の変化により現 れる可能性も考えられる.このように, クエット乱流 中に現れるストリーク構造は複雑であり, 大規模構造 を明確にとらえることは難しい。ここで得られた $u_{1}^{\prime}$ のスパン方向の相関を図 7 に示す。熱線から得られた 相関は, $\Delta x_{3} /(2 h)=0.8$ 付近で最小值(約一0.25)をと り, 可視化から得られた相関とよく一致しており，い ずれの測定も同様のストリークのスパン方向に関する 空間構造をとらえていることがわかる. 図 7 には示し ていないが $R e_{b}=10000$ でも測定を行い $R e_{b}=15000$ と同じ結果を得た。

可視化実験の場合と同じように $u_{1}^{\prime}\left(x_{1}, x_{3}\right)$ の二次元 ウェーブレットエネルギースペクトルを求めた。 スペ クトルの主流方向への分解は, $j_{1}=1$ から $j_{1}=18$ の 18 個, スパン方向の分解は, $j_{3}=1$ から $j_{3}=4$ の 4 個であ る.ウェーブレットエネルギースペクトルを図 11 に 示す. 比較のためにポアズイユ乱流のスペクトルも示 してある. 各スケールパラメータ $j_{1}, j_{3}$ に対応するス ケールを図11 中の括弧内に示してある.ここでは図 を見やすくするためにスパン方向のスケールパラメー 夕 $j_{3}=4$ のスペクトルは, 省いてある. なお省いた部 分が保有するエネルギーの割合は, クエット乱流で $12 \%$, ポアズイユ乱流で $14 \%$ であった.

ここで得られた特徵的な分布が $j_{3}=2,3$ に見られ る. 説明のため, $j_{3}=3$ の場合を図 12 に示す. 主流方 向に比較的大きなスケールの $j_{1}=9$ のエネルギーのピ ークがあり，それより小さなスケールの $j_{1}=11,12$ に これょり弱い盛上がりが見られる. Kim-Adrian ${ }^{(6)}$ は, 高レイノルズ数のポアズイユ乱流の外層で同様の フーリエパワースペクトルを得ており,これを図 12 中二点鎖線で示すように分割し，それぞれが大規模構 造と小スケールの運動からの寄与によるものであると 解釈している. 図11 からわかるように大規模構造の スケールは，およそ主流方向に $34 h$ ，スパン方向に $2 h$ 程度であり，これはスモークワイヤ法で得られたウェ ーブレットスペクトルの構造と同じであることがわか る.このことょり,ここで考察の対象としている大き

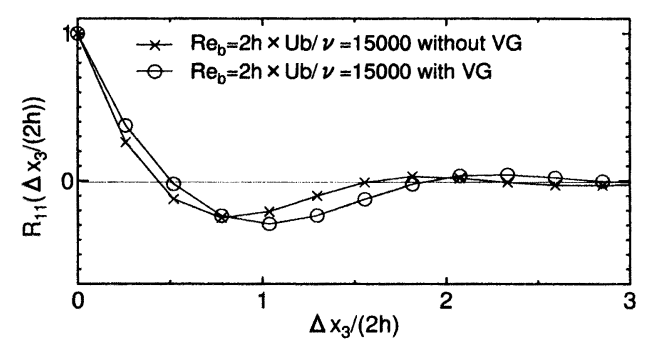

Fig. 14 Spanwise correlations of streamwise velocity with and without VG

いスケールの構造に関しては熱線のデータにテイラー の凍結乱流の仮説を用いて空間構造を考察できること が間接的に示されたことになる。この大規模構造を抽 出するために $E_{j_{1}: j_{4}}$ に示した矢印の部分のモード $\left(j_{1}\right.$ $=9)$ を含む $\left(j_{1}=8,9,10, j_{3}=2,3\right)$ だけを取り出して速 度場の再構成 $\left[u_{1}^{L}\left(x_{1}, x_{3}\right)\right]$ を行うと図 13 のようにな る. 主流方向に長さ $\Delta x_{1} /(2 h)=10 \sim 40$ 程度, スパン 方向に幅 $\Delta x_{3} /(2 h)=1$ 程度のストリークが確認でき, 図 9 で述べたように $40 \leq \Delta x_{1} /(2 h) \leq 80$ におけるスパ ン方向への摇らぎが明確になっている。また， $\Delta x_{1} /(2 h)=10$ 程度のスケールのストリークがランダ ムに存在する領域 $\left(\Delta x_{1}<40\right)$ と比較的長いストリーク が存在する領域 $\left[40 \leq \Delta x_{1} /(2 h) \leq 80\right]$ がある. 一方, ポアズイユ乱流においては, このような大規模構造に よるピークは存在せず,すべてのスケールパラメータ $j_{3}=1,2,3$ において $j_{1}=13$ でピークをもつ分布とな る.ポアズイユ乱流の流路中央部に扔いては, 主流方 向に流路高さ $2 h$ 程度の長さスケール(スケールパラ メータ $j_{1}=13$ に対応する)の構造がおもに乱れの工ネ ルギーに寄与している.

以上の上うに熱線を用いて, クエット乱流中に現れ るストリーク構造の概略が知られたが, 図 9 に見るよ うにストリークは途中で途切れたり, ランダムに現れ たりするためにその特性を調べることが難しい。そこ で, vortex generator (VG) で䋛渦のペアを導入し(3), 途中で途切れることのないストリークを作り，このス 
トリークの空間構造を調べた。VGは, $x_{1} /(2 h)=76$ に設置し，VGによる直接の影響が消え準定常的な縦 渦が得られる $x_{1} /(2 h)=110$ より下流で測定した.VG を設置した場合とそうでない場合のスパン方向の相関 は，ほほ同じ位置で最小值をとり，最小值の值もほぼ 等しい(図 14)。また，ウェーブレットエネルギースペ クトルは, 図11に示すようにVGを設置した場合に は, $j_{3}=3$ でのエネルギーが若干隇少しているものの VG をつけない場合の特徵をもち, ストリークの統計 的性質はVGの有無によらず同じである. Hamilton $ら^{(4)}$ のミニマル平面クエット乱流のシミュレーショ ンでは， $x_{1}$ 方向に周期境界条件が採用されており，ま た流れ場にはつねに大規模縦渦が存在しているため, 流路入口では, 強制的に縦渦を導入していることにな る.この点で, VGにより綐渦を導入した場合のスト リーク構造とミニマル平面クエット乱流のそれは類似 しており,これらを比較検討することはクエット乱流 中の大規模構造を考察するうえで興味のあることであ る.

Hamilton ら (4) が示したようなストリーク構造の時 間発展をこの実験結果から調べることはできない。し かし，多くのサンプルを集ることによりストリーク再 生サイクルの各段階におけるスナップショットを見る ことは可能である. VG を取付けた場合の $u_{1}^{\prime}\left(x_{1}, x_{3}\right)$ の分布を図 15 に示す。この低速ストリークの $x_{1}$ 方向 への変化は, 図 15(a)のようにスパン方向に摇らいで ジグザグ構造を示す場合と図 15（b）のようにまっす ぐに伸びる場合がある。これは, Hamilton らが示し たストリークの時間発展サイクル，すなわちストリー クのジグザグ配置と直線配置を繰返すサイクルに対応 している. VG を導入した場合の低速ストリークのス パン方向の摇らぎはスモークワイヤ法による可視化に おいても観測されており（図 16），VGを取付けた場合 のクエット乱流の 16 チャネルI 形熱線による測定が, ストリークの空間構造をよくとらえてることがわか る. 低速ストリークのスパン方向への摇らぎを定量的 に評価するためにストリークの主流方向に対する傾き を調べた。低速ストリークの $x_{1}$ 方向に対する傾き角 $\theta$ は, 次のようにして求めた。ある $x_{10}$ における $u_{1}^{\prime}\left(x_{10}, x_{3}\right)$ が最小值をとるスパン方向位置 $x_{3 \min }$ を求 める. $x_{3 \min }$ をこの $x_{10}$ でのストリークの中心位置とす る.すべての $x_{1}$ に関してこの計算を行うと断面 $\left(x_{1}\right.$, $\left.x_{3}\right)$ 内にストリークの軌跡が曲線として得られる(図 17).この曲線の $x_{1}$ への傾き $\theta$ を低速ストリークの 傾きとした。この $\theta$ の分布を図 18 に示す. 図 18 中 の矢印の区間は, 図 15(a), (b)に対応している。図

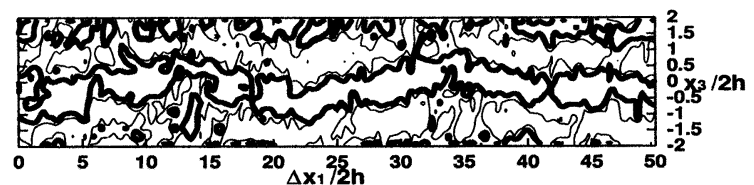

(a) Meandering streak

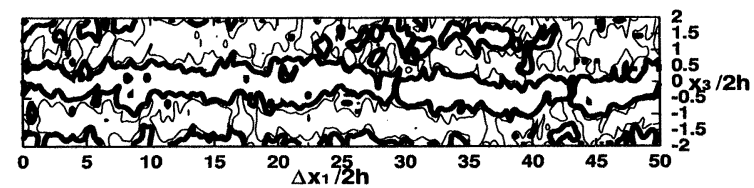

(b) Straight streak

Fig. 15 Equi-velocity contours of $u_{1}^{\prime}\left(x_{1}, x_{3}\right)$ with VG at center plane: thick lines depict $u_{1}^{\prime} / U_{c}=-0.05$ and thin lines $u_{1}^{\prime} / U_{c}=0.05$

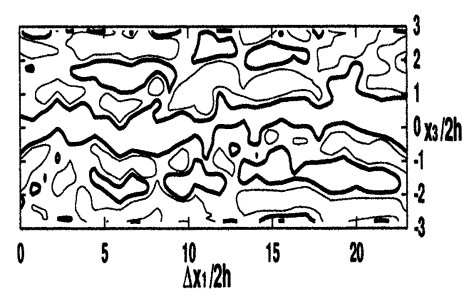

Fig. 16 Equi-velocity contours of $u_{1}^{\prime}\left(x_{1}, x_{3}\right)$ with VG at center plane: the velocity measured by smokewire visualization

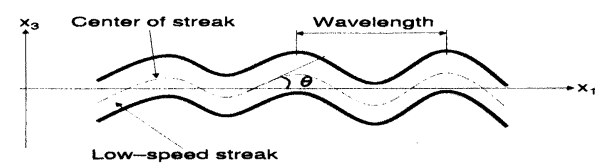

Fig. 17 Inclination angle of streak

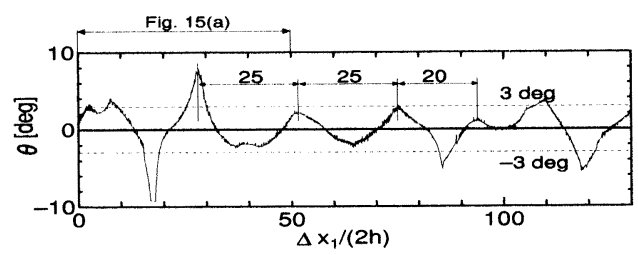

(a)

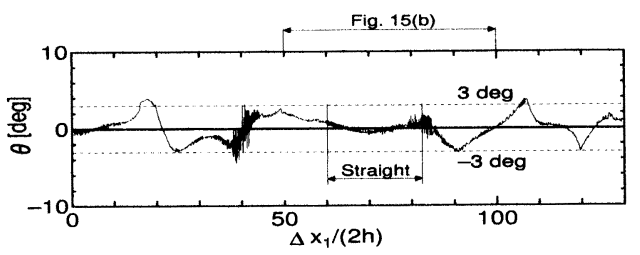

(b)

Fig. 18 Inclination angle of streak of Couette flow with $\mathrm{VG}$ at $R e_{b}=15000$ 


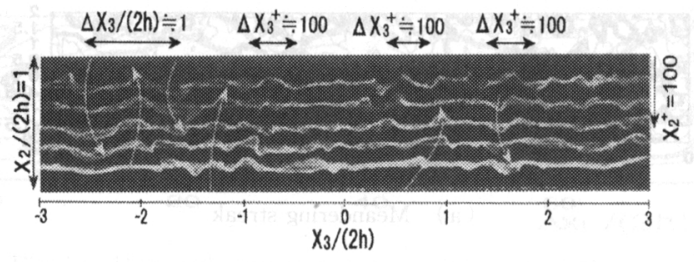

Fig. 19 Smoke-wire visualization in $x_{2}-x_{3}$ plane of Couette flow at $\operatorname{Re}_{b}=700\left(\operatorname{Re}^{*}=100\right)$

18（a）より,ストリークの $x_{1}$ に対する傾きは, 約 $\pm 3^{\circ}$ で, $x_{1}$ 方向に周期的に変化し, その波長は, ほぼ $(20 \sim 25) \times 2 h$ 程度であることがわかる. 一方, 図 $18(b)$ では, $\theta$ の周期性は見られず, 部分的に $\theta \approx 0$ の直線部分も見られる不規則な変化となっている. Hamilton らの示したミニマル平面クエット乱流にお ける再生サイクルに現れるストリークのスパン方向の 摇らぎの波長は, $3 \times 2 h$ 程度で本実験で得られたスト リークの波長とは 7〜8倍程度の違いがある. ミニマ ルクエット乱流においては, 主流方向の周期境界条件 により特定の波長をもつストリークの摇らぎが強調さ れる可能性がある. 実際, ミニマルクエット乱流に現 れるストリークの摇らぎの波長は主流方向の計算領域 の長さと一致している. 一方, 本研究においては, そ のような主流方向への周期性の制限はない. 両者の流 れ場の主流方向への条件の相違がストリークの摇らぎ の波長の違いを生じさせたものと考えられる.しか し, 波長は違うものの, 本実験のクエット乱流におけ るストリークがジグザグ配置と直線配置のパターンを 示しており, ストリークの生成と崩壊の一連のサイク ルが現れているものと考えられる.

$4 \cdot 2$ 縦渦の可視化 断面 $\left(x_{2}, x_{3}\right)$ 内において, ス モークワイヤ法によりクエット乱流中の縦渦運動に関 連する壁垂直速度成分の可視化を行った. 図 19 に断 面 $\left(x_{2}, x_{3}\right)$ の可視化写真を示す. 可視化写真より断面 を横切って壁から流路中央へ連なる壁垂直方向の大規 模な運動があることがわかる(図 19 中の矢印).これ は, 主流方向を向いた大規模縦渦による対流運動によ るものと考えられ, このような対流運動により大規模 ストリークが生成される。一方, 壁面近く(壁にいち ばん近いワイヤの位置は, $\left.x_{2}^{+} \equiv x_{2} u^{*} / \nu=33\right)$ では, 図 19 中の上壁側に示したように $\Delta x_{3}^{+} \equiv \Delta x_{3} u^{*} / \nu \approx 100$ 間 隔にイゼクションが観察される.このイゼクションの 一部は, 大規模対流運動に連なっているが, そうでな いものもある.この大規模運動に関連したイゼクショ ンの間隔は, 上壁において $\Delta x_{3} /(2 h) \approx 1$ 程度となる.
可視化写真から流路中央部の大規模スケールが壁近傍 と一部つながりがあることから, 内層と外層の相互作 用の存在を推測することができる。

\section{5. 結 論}

（1）クエット乱流の二次元ウェープレットエネル ギースペクトルは, 大規模ストリーク構造と小スケー ルの運動に対応した位置に盛上がりが見られる．大規 模ストリークに対応するスケールだけを取り出して再 構成した結果, このストリークは流れ方向に $(10 \sim 40)$ $\times 2 h$ 程度, スパン方向に $2 h$ 程度のサイズである.

（2）VG を設置した場合とそうでない場合のウェ ーブレットエネルギースペクトルと $u_{1}^{\prime}$ のスパン方向 の相関は, ほほ等しく双方の統計的な性質は等しい.

（3）クエット乱流中において, 縦渦(VGで生成) により強制的に導入したストリークは, ジグザグ配置 をとる場合と直線配置をとる場合がある、ストリーク がジグザグ配置をとるときのスパン方向の摇らぎの波 長は，(20～25) $\times 2 h$ 程度である。本実験では主流方向 への傾き角は, ほほ $\pm 3^{\circ}$ であった。

(4) 断面 $\left(x_{2}, x_{3}\right)$ の可視化によりスパン方向に $\Delta x_{3}^{+} \approx 100$ 程度の間隔をもつイゼクションと大規模縦 渦運動による大きな対流運動が観測された。壁からの イゼクションによる運動は, 流路中央, あるいは他方 の壁面にまで及ぶ場合もある。これは，流路中央部の 大規模縦渦の対流運動と関連しており, 内層と外層と の相互作用の存在を示している.

\section{文献}

(1) Komminaho, J., ほか 2 名, Very Large Structures in Plane Turbulent Couette Flow, J. Fluid Mech., 320 (1996), 259-285.

(2) Tillmark, N. and Alfredsson, P. H., Large Scale Struc ture in Turbulent Couette Flow, $A d v$. Turbulence, VII (1998), 59-62.

（3）梅木雅之・鬼頭修己, 平面クエット乱流の大規模縦渦構 造の維持機構の解明, 機論, 69-684, B (2003), 1807-1813.

(4) Hamilton, J. M., ほか2 名, Regeneration Mechanism of Near-Wall Turbulence Structures, J. Fluid Mech., 287 (1995), 317-348.

(5) Kawahara, G. and Kida, S., Periodic Motion Embedded in Plane Couette Turbulence: Regeneration Cycle and Burst, J. Fluid Mech., 449 (2001), 291-300.

(6) Kim, K. C. and Adrian, R. J., Very Large-Motion in the Outer Layer, Phys. Fluids, 11 (1999), 417-422.

(7) Li, H. and Zhou, Y., Multi-Scale Eddy Structure Identification in a Turbulent Near-Wake Using Wavelet Analysis, Proc. 3rd Int. Symp. Turbulence, Heat Mass Transf., (2000), 629-636.

（8）山口昌哉・山田道夫, ウェーブレット解析, 科学, 岩波書 店, 60-6(1990), 398-405. 